Biogeosciences, 10, 327-338, 2013

www.biogeosciences.net/10/327/2013/

doi:10.5194/bg-10-327-2013

(C) Author(s) 2013. CC Attribution 3.0 License.

\title{
Ammonia emissions from cattle urine and dung excreted on pasture
}

\author{
J. Laubach ${ }^{1}$, A. Taghizadeh-Toosi ${ }^{2, *}$, S. J. Gibbs ${ }^{3}$, R. R. Sherlock ${ }^{2}$, F. M. Kelliher ${ }^{4}$, and S. P. P. Grover ${ }^{1, * *}$ \\ ${ }^{1}$ Landcare Research, Lincoln, New Zealand \\ ${ }^{2}$ Department of Soil and Physical Sciences, Lincoln University, Lincoln, New Zealand \\ ${ }^{3}$ Department of Agricultural Sciences, Lincoln University, Lincoln, New Zealand \\ ${ }^{4} \mathrm{Ag}$ Research, Lincoln Research Centre, Lincoln, New Zealand \\ *now at: Department of Agroecology, Aarhus University, Tjele, Denmark \\ ** now at: Department of Civil Engineering, Monash University, Melbourne, Australia
}

Correspondence to: J. Laubach (laubachj@landcareresearch.co.nz)

Received: 30 August 2012 - Published in Biogeosciences Discuss.: 26 September 2012

Revised: 7 December 2012 - Accepted: 19 December 2012 - Published: 23 January 2013

\begin{abstract}
Twelve cattle were kept for three days in a circular area of $16 \mathrm{~m}$ radius on short pasture and fed with freshlycut pasture. Ammonia $\left(\mathrm{NH}_{3}\right)$ emissions from the urine and dung excreted by the cattle were measured with a micrometeorological mass-balance method, during the cattle presence and for 10 subsequent days. Daily-integrated emission rates peaked on Day 3 of the experiment (last day of cattle presence) and declined steadily for five days thereafter. Urine patches were the dominant sources for these emissions. On Day 9, a secondary emissions peak occurred, with dung pats likely to be the main sources. This interpretation is based on simultaneous observations of the $\mathrm{pH}$ evolution in urine patches and dung pats created next to the circular plot. Feed and dung samples were analysed to estimate the amounts of nitrogen $(\mathrm{N})$ ingested and excreted. Total $\mathrm{N}$ volatilised as $\mathrm{NH}_{3}$ was $19.8( \pm 0.9) \%$ of $\mathrm{N}$ intake and $22.4( \pm 1.3) \%$ of $\mathrm{N}$ excreted. The bimodal shape of the emissions time series allowed to infer separate estimates for volatilisation from urine and dung, respectively, with the result that urine accounted for $88.6( \pm 2.6) \%$ of the total $\mathrm{NH}_{3}$ emissions. The emissions from urine represented $25.5( \pm 2.0) \%$ of the excreted urine- $\mathrm{N}$, while the emissions from dung amounted to $11.6( \pm 2.7) \%$ of the deposited dung-N. Emissions from dung may have continued after Day 13 but were not resolved by the measurement technique. A simple resistance model shows that the magnitude of the emissions from dung is controlled by the resistance of the dung crust.
\end{abstract}

\section{Introduction}

Ammonia $\left(\mathrm{NH}_{3}\right)$ is generated at the soil surface, often in abundant quantities, shortly following the surface application of any source of ammoniacal- $\mathrm{N}\left(\mathrm{NH}_{\mathrm{x}}-\mathrm{N}\right.$, combining $\mathrm{NH}_{3}-\mathrm{N}$ and $\mathrm{NH}_{4}^{+}-\mathrm{N}$ ) that also induces an increase in soil-surface $\mathrm{pH}$. Sources include urea and other ammoniacal fertilisers, ammoniacal wastes and ruminant urine (Sherlock et al., 1995). Such $\mathrm{NH}_{3}$ is susceptible to volatilisation at rates which can vary extensively depending on the crop, cultural conditions, soil properties, dung or urine deposition rates and method of fertiliser application: e.g. for urea from $1.7 \%$ to $56 \%$ of the applied N (Ryden et al., 1987; Jarvis et al., 1989; Sherlock et al., 1989, 2008), or for slurry from $4 \%$ to over $60 \%$ (Sintermann et al., 2012). Ammonia volatilisation from agricultural soils is a dominant factor in the formation of atmospheric secondary aerosols due to its reaction with nitric and sulphuric acids in the atmosphere (Nemitz et al., 2009). These aerosols contribute to the formation of acid rain (Bobbink et al., 1992). Ammonia volatilisation decreases methane $\left(\mathrm{CH}_{4}\right)$ oxidation rates in soils (Mosier et al., 1997), and acts as an indirect source of nitrous oxide $\left(\mathrm{N}_{2} \mathrm{O}\right)$ when the $\mathrm{NH}_{3}$ is deposited downwind onto land surfaces (van der Eerden, 1982; Bobbink et al., 1992; Barthelmie and Pryor, 1998). $\mathrm{As} \mathrm{NH}_{3}$ is emitted, it is transported away from the soil surface by the wind both vertically and horizontally. These conditions are far removed from those typically experienced under laboratory conditions and consequently emissions under field conditions can differ substantially from $\mathrm{NH}_{3}$ volatilisation losses measured in the laboratory (Fenn and Hossner, 1985). 
Ammonia emissions can be measured under field conditions by micrometeorological methods. Laubach et al. (2012) compared several such methods to measure and model the $\mathrm{NH}_{3}$ emissions from a circular plot of pasture soil, of $15 \mathrm{~m}$ radius, which had been treated with dairy cow urine deposited in a regular array of 132 "urine patches". The treatment rate used simulated the urine amounts and number of urination events expected from a dozen dairy cows grazing that area for $24 \mathrm{~h}$ (thereby simulating a grazing time and stocking density that are typical for rotational grazing practice on dairy farms in Canterbury, New Zealand). Laubach et al. (2012) concluded that of the tested methods, the massbudget method was the most accurate. This method is applied in the experiment reported here, which represents a more realistic farming situation where the emissions from both urine and dung are measured as they are excreted by the cattle in situ. Similar experiments were conducted by Bussink (1992, 1994) in the Netherlands.

Apart from the practical challenges of handling live cattle around measurement equipment, an added difficulty of the in-situ approach is that neither the amounts of excreta deposited, nor their $\mathrm{N}$ contents, can be controlled. These can, however, be estimated, provided the feed intake of the cattle is known. In order to control, measure and chemically characterise the feed intake in this experiment, the cattle were prevented from grazing by mowing the pasture prior to the start, and offering them grass that had been freshly harvested nearby ("cut and carry"). While the provision of feed as such resembles feedlot practice rather than grazing, the experimental setup differed from true feedlots in several important aspects: the feed composition provided was equal to that in a grazing situation, the excreta were deposited on pasture soil with short herbage cover and left to their natural decomposition processes, and the cattle were removed after $3 \mathrm{~d}$, leaving the excreta undisturbed after that time while $\mathrm{NH}_{3}$ emissions were continuously measured until close to the resolution limit of the measurement method.

The results of this experiment therefore quantify the combined effect of $\mathrm{NH}_{3}$ emissions from urine and dung, in conditions similar to a real rotational-grazing practice, and in weather conditions comparable to the experiment of Laubach et al. (2012). The observed emissions are further interpreted in the context of conversion processes in the dung, which were simultaneously investigated by analysing samples repeatedly taken from dung pats that had been created in a controlled fashion.

\section{Materials and methods}

\subsection{Site and schedule}

The experiment was conducted in a paddock located $3 \mathrm{~km}$ south of Lincoln University, New Zealand $\left(43^{\circ} 40.45^{\prime} \mathrm{S}\right.$, $172^{\circ} 28.22^{\prime} \mathrm{E}, 4 \mathrm{~m}$ a.s.1.). The soil was classified as a Temple- ton silt loam (N. Smith and P. Almond, Lincoln University, personal communication, 2011). A circle with $16 \mathrm{~m}$ radius was fenced as the experimental plot and the pasture mown to ca. $5 \mathrm{~cm}$ height. For the first three days, 12 non-lactating cattle with average live-weight of $470 \mathrm{~kg}$ were kept in the experimental plot. The stocking density represented by this setup (150 animals $\mathrm{ha}^{-1}$ ) was typical for rotational grazing practice in New Zealand, but the cattle-presence period was 3 to 6 times longer than the feed supply in a real-world grazing situation would normally last. This longer period was chosen so that a sufficient amount of urine and dung was deposited to produce a well-resolvable $\mathrm{NH}_{3}$ emission signal. Implications of the higher excreta density are discussed in Sect. 4.1.

The cattle were excluded from an area of $1.4 \mathrm{~m}$ radius in the centre of the circle, where the $\mathrm{NH}_{3}$ samplers were installed. Meteorological and soil measurements (details below) were conducted outside the circle, ca. $40 \mathrm{mE}$ of the circle's centre.

The start of the experiment was defined as the time when the cattle entered the fenced circle, at 16:05 LT on 8 March 2011. The cattle departed at 16:20 LT on 11 March, $3.01 \mathrm{~d}$ later, and the $\mathrm{NH}_{3}$ measurements were discontinued in the morning of 21 March, at $12.75 \mathrm{~d}$.

\subsection{Feed supply and analyses}

The cattle were provided with freshly-cut pasture made up mainly from ryegrass (Lolium perenne) and white clover (Trifolium repens). The feed originated from a paddock nearby. It was provided ad libitum, twice daily, at 9:00 LT and 16:00 LT. The feed was laid out around the perimeter of the plot, to encourage the cattle to spread evenly across the area - which they did, judging from casual observation of their behaviour as well as from the distribution of dung pats, inspected after the cattle had left.

The offered feed was weighed. Feed samples were taken, dried, dry matter (DM) contents determined, and subsamples taken for chemical analysis. Prior to the morning feeding, any refused feed from the previous day was raked together and also weighed and its DM content determined. DM digestibility was determined by near-infrared reflectance spectroscopy (NIRS). Total carbon (C) and nitrogen (N) in the grass samples were obtained with an elemental analyser (Vario-Max $\mathrm{CN}$, Elementar $\mathrm{GmbH}$, Hanau, Germany), the samples being combusted at $900^{\circ} \mathrm{C}$ in an oxygen atmosphere. This process converted any elemental $\mathrm{C}$ and $\mathrm{N}$ into $\mathrm{CO}_{2}, \mathrm{~N}_{2}$ and $\mathrm{NO}_{\mathrm{x}}$. The $\mathrm{NO}_{\mathrm{x}}$ was subsequently reduced to $\mathrm{N}_{2}$. The $\mathrm{CO}_{2}$ and $\mathrm{N}_{2}$ gases were then passed through a thermal conductivity cell to determine their concentrations. The fractions of $\mathrm{C}$ and $\mathrm{N}$ (\%) were calculated from these concentrations and the sample weights. 


\subsection{Urine and dung measurements}

In order to characterise the physical and chemical processes causing $\mathrm{NH}_{3}$ emissions from the excreta, a few urine patches and dung pats were created to measure $\mathrm{pH}$ and take samples for laboratory analyses. These urine patches and dung pats were placed outside the circular cattle area, near the meteorological sensors. On each of four subsequent afternoons, firstly when the cattle entered the circle and finally when they departed, one urine patch and two dung pats were created. The daily intervals were intended to represent the variability in the evolution of soil and weather conditions that the excreta produced by the cattle in the circle would have been subjected to, depending on their time of deposition.

The urine required had been collected at the Lincoln University dairy farm and was stored at $4{ }^{\circ} \mathrm{C}$ until needed. The urine patches were created with the method of Laubach et al. (2012): for each patch, $1.5 \mathrm{~L}$ urine was poured from a plastic bottle into a funnel with bendable tubing attached to the outlet. The tubing outlet was at $1.2 \mathrm{~m}$ above ground, and the urine ran out within 15 to $20 \mathrm{~s}$, covering a soil area of about $0.25 \mathrm{~m}^{2}$.

The dung was collected inside the experimental plot, from selected pats that appeared freshest, and then applied at the target location by filling a ring of $25 \mathrm{~cm}$ diameter that was placed on the ground, to a height of 3 to $5 \mathrm{~cm}$. The ring was subsequently removed. Of each daily pair of dung pats, one was designated for surface $\mathrm{pH}$ measurements, the other for the removal of samples of the crust and the interior. Crust samples were taken daily, one from each of these four pats. Interior samples were taken from one pat per day, in triplicates, and the next pat the next day etc., so that effectively each pat was sampled every fourth day. Upon arrival in the lab, the dung crust and dung interior samples were frozen, then weighed and placed in a freeze-dryer (FD 5.5, Cuddon Ltd., Blenheim, NZ) for $48 \mathrm{~h}$. After that they were re-weighed and their gravimetric moisture contents were determined. The amounts of ammonium- $\mathrm{N}\left(\mathrm{NH}_{4}^{+}-\mathrm{N}\right)$, nitrite- $\mathrm{N}\left(\mathrm{NO}_{2}^{-}-\mathrm{N}\right)$, nitrate- $\mathrm{N}\left(\mathrm{NO}_{3}^{-}-\mathrm{N}\right)$ were obtained with a twin-channel flow injection analyser (FS 3000, Alpkem, College Station, TX, USA). Total C and $\mathrm{N}$ of dung subsamples were obtained with the same elemental combustion method as for the grass samples.

Since a hard hydrophobic crust formed quite rapidly on the dung pats, their surface $\mathrm{pH}$ was measured in the field, using a portable $\mathrm{pH}$ electrode (HI 9025, Hanna Instruments, Woonsocket, RI, USA) with a flat-surface electrode (Broadley-James, Irvine, CA, USA). Measurements were made in the middle of each daytime $\mathrm{NH}_{3}$ collection period, on the surface of one dung pat from each creation day (the one not used for taking samples) and also on the surface of each urine patch. Each measurement consisted of five replicate readings, taken at different locations on the surface. The $\mathrm{pH}$ of the dung interior was determined less frequently, using the samples taken to the lab, with the same portable electrode as in the field.

\subsection{Meteorological and soil measurements}

Wind speed was measured by five cup anemometers (A101M, Vector Instruments, Rhyl, Co. Clwyd, UK) with matched calibrations. They were installed at five sampling heights, $0.25,0.50,0.75,1.25$ and $2.10 \mathrm{~m}$ above the ground on a mast $40 \mathrm{mE}$ of the circle's centre. Rainfall was recorded by a tipping-bucket rain gauge (Ogawa Seiki, Tokyo, Japan) with a resolution of $0.167 \mathrm{~mm}$. Soil temperature was measured by thermocouples buried at two depths ( 2 and $5 \mathrm{~cm}$ ), in two replicates, near the wind profile mast. Soil moisture was monitored continuously with five water content reflectometers (CS-616, Campbell Scientific, Logan, UT, USA). These were buried horizontally, four of them at $2 \mathrm{~cm}$ depth, one under each urine test patch, and one at $5 \mathrm{~cm}$ depth in urine-free soil. The soil moisture data were corrected for temperature in post-processing. All meteorological variables were recorded by a datalogger (CR-3000, Campbell Scientific, Logan, UT, USA), as 10-min averages.

\subsection{Ammonia collection and mass-budget method}

$\mathrm{NH}_{3}$ emission rates were determined with the micrometeorological mass-budget method (Beauchamp et al., 1978; Denmead, 1995). In the centre of the fenced circle, vertical profiles of the horizontal $\mathrm{NH}_{3}$ flux were measured with "Leuning samplers" (Leuning et al., 1985). These devices have a vertical rotation axis that allows them to point into the wind and respond quickly to wind direction changes, similar to a wind vane. As air passes continuously through a sampler, the $\mathrm{NH}_{3}$ content of that air is completely removed by reaction with a solid oxalic acid coat. This coat must be applied to a complex array of internal surfaces prior to sampling. At the end of the sampling period, the sampler needs to be exchanged for an identical one in order to continue collection, while the reaction product, $\left(\mathrm{NH}_{4}\right)_{2} \mathrm{C}_{2} \mathrm{O}_{4}$ (ammonium oxalate), is retrieved in the lab by a discharging procedure (described in Laubach et al., 2012) and converted to $\mathrm{NH}_{\mathrm{x}}$ in aqueous solution.

$\mathrm{NH}_{3}$ samplers were installed at the same five heights as the cup anemometers. A simple mass budget is constructed in the atmospheric surface layer, for the vertical plane that contains the measurement mast and is aligned with the wind direction. In this mass budget, all the $\mathrm{NH}_{3}$ gas carried horizontally past the mast (in the centre of the source area) must originate from surface sources along the radius of the circular plot upwind of the mast, except for a background contribution carried by the air entering the circle at its perimeter. This background contribution is assumed height-constant. To quantify it, a sixth sampler was installed at $2.10 \mathrm{~m}$ height ca. $50 \mathrm{~m}$ away from the circle's centre. To ensure in practice that this sampler operated in upwind air, it was mounted 
on one of four masts that had been placed to the NW, NE, SE and SW, whichever suited best the anticipated wind direction. Further details concerning the evaluation of the $\mathrm{NH}_{3}$ profiles and subsequent computation of the $\mathrm{NH}_{3}$ emission rate are given in Laubach et al. (2012) and in the Supplement.

Nighttime $\mathrm{NH}_{3}$ collection periods were 14 to $16 \mathrm{~h}$ long. During the cattle presence and the following two days, daytime collection periods lasted $4 \mathrm{~h}$. They were increased to $5 \mathrm{~h}$ for the next two days and then to a single day-time period, between 7 and $8 \mathrm{~h}$ long, for three days. The final collection period lasted $64 \mathrm{~h}$ (three nights and the two intervening days).

\subsection{Ammonia analysis}

Solutions extracted from the $\mathrm{NH}_{3}$ samplers were initially analysed with an ion-specific electrode (ISE-10-10-00, HNU Systems, Newton, MA, USA), as in Laubach et al. (2012). However, the subsequently computed $\mathrm{NH}_{3}$ emission rates were unexpectedly high. A few $\mathrm{NH}_{3}$ subsamples were then re-analysed by two different methods, on a flow injection analyser (FIA, the same as for the dung analyses) and on a clinical chemistry analyser (Daytona LT090, Randox Ltd., Crumlin, Co. Antrim, Northern Ireland). Both these methods confirmed that the prepared $\mathrm{NH}_{3}$ standards for the electrode were correct, and both indicated that the field-collected $\mathrm{NH}_{3}$ concentrations were by a factor 2 to 3 smaller than determined by the $\mathrm{NH}_{3}$ electrode calibrated against these standards. From considerations detailed in the Appendix, it was concluded that the electrode was strongly sensitive to the presence of volatile amines, which were probably eructated by the cattle.

Subsamples from all $\mathrm{NH}_{3}$ collections were thus reanalysed in a single batch on the clinical chemistry analyser (CCA). This instrument uses an enzymatic reaction to strip all $\mathrm{NH}_{3}$ from the test solution and measures the difference in UV absorbance at $340 \mathrm{~nm}$ before and after the reaction. The precision of this method is specified by the manufacturer as 1 to $4 \%$ of the absolute reading (range-dependent). This is comparable to the $2.3 \%$ relative error estimated for the $\mathrm{NH}_{3}$ electrode (Laubach et al., 2012). However, the detection limit is a factor 20 larger than for the electrode, which is likely to affect the accuracy of the samples collected at the upper heights towards the end of the experiment, and the upwind background samples throughout.

As an additional check, two selected samples were analysed for their total Kjeldahl nitrogen content (Hill Laboratories, Hamilton, New Zealand).

\section{Results}

\subsection{Soil and weather conditions}

Some rain fell prior to the experiment, on 5 and 6 March, and the soil dried from 0.17 to $0.10 \mathrm{~m}^{3} \mathrm{H}_{2} \mathrm{O}\left(\mathrm{m}^{3} \text { soil }\right)^{-1}$ during the first week of measurements (Fig. 1). Only a negligible

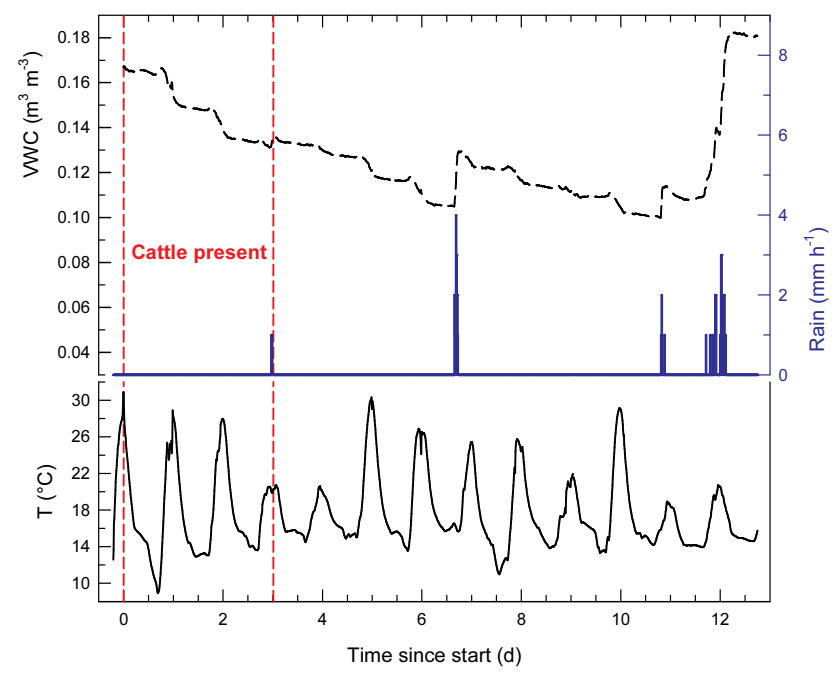

Fig. 1. Temporal evolution of volumetric water content (top) and soil temperature (bottom) at $2 \mathrm{~cm}$ depth, as well as rainfall intensity (centre). The origin of the time axis is at 16:05 LT on 8 March 2011, when the cattle entered the circular plot.

soil moisture increase was observed when $0.3 \mathrm{~mm}$ of drizzle fell at $2.98 \mathrm{~d}$, just before the cattle departed. Rain events that noticeably increased soil moisture occurred on three occasions: $3 \mathrm{~mm}$ at 6.66 to $6.72 \mathrm{~d}$ after the start of the experiment, $1 \mathrm{~mm}$ at 10.81 to $10.88 \mathrm{~d}$, and $5 \mathrm{~mm}$ intermittently between 11.72 and $12.11 \mathrm{~d}$. Soil moisture measured under the urine test patches increased by $0.03 \mathrm{~m}^{3} \mathrm{H}_{2} \mathrm{O}\left(\mathrm{m}^{3} \text { soil }\right)^{-1}$ immediately after their creation and gradually decreased towards background soil moisture over several days.

Soil temperature at $2 \mathrm{~cm}$ depth reached afternoon maxima of 31,28 and $27^{\circ} \mathrm{C}$ on the start day and the following two days, respectively, favouring rapid urea hydrolysis in the freshly deposited excreta. The day of the cattle departure and the next day were overcast and cooler, with soil temperature maxima of $20^{\circ} \mathrm{C}$. Peaks on the following four days were again above $25^{\circ} \mathrm{C}$. Nocturnal minima varied between 9 and $16^{\circ} \mathrm{C}$, and overall mean soil temperature of the 13 days of measurement was $18^{\circ} \mathrm{C}$, both at $2 \mathrm{~cm}$ and $5 \mathrm{~cm}$.

\subsection{Estimation of nitrogen deposited with the excreta}

The total grass weight offered to the group of cattle on each of the 6 feeding occasions varied between 419 and $546 \mathrm{~kg}$. The DM content was around $14 \%$ in the mornings and $16 \%$ in the afternoons (overall mean $\pm \mathrm{SE}$ was $15.2 \pm 0.5 \%$ ). This resulted in a total DM offered of $446 \mathrm{~kg}$, of which $67 \mathrm{~kg}$ were refused. Each animal consumed $10.53( \pm 0.35) \mathrm{kg}$ DM per day on average. Nitrogen content as a fraction of DM was determined for each feeding occasion, as $2.59( \pm 0.07) \%$ (mean $\pm \mathrm{SE}$ ). The total $\mathrm{N}$ intake throughout the 3-d period was thus $9.81( \pm 0.42) \mathrm{kg}$, representing $0.273( \pm 0.012) \mathrm{kg} \mathrm{N} \mathrm{d}^{-1}$ animal $^{-1}$. Some of this $\mathrm{N}$ intake was retained by the cattle in the form of liveweight 
Table 1. Amounts of nitrogen fed, deposited and volatilised as well as their ratios. Uncertainties (in parentheses) are propagated standard errors.

\begin{tabular}{llllll}
\hline $\begin{array}{l}\text { N budget } \\
\text { component }\end{array}$ & $\begin{array}{l}\mathrm{N} \text { amount } \\
(\mathrm{kg})\end{array}$ & $\begin{array}{l}\text { Fraction of N } \\
\text { intake }(\%)\end{array}$ & $\begin{array}{l}\text { Fraction of N } \\
\text { excreted (\%) }\end{array}$ & $\begin{array}{l}\text { Fraction of } \\
\text { dung-N (\%) }\end{array}$ & $\begin{array}{l}\text { Fraction of } \\
\text { urine-N (\%) }\end{array}$ \\
\hline intake & $9.81(0.42)$ & 100 & & \\
\hline $\begin{array}{l}\text { retained } \\
\text { excreted }\end{array}$ & $1.13(0.25)$ & $11.5(2.6)$ & & \\
\hline $\begin{array}{l}\text { in dung } \\
\text { in urine }\end{array}$ & $1.98(0.49)$ & $88.5(2.6)$ & 100 & & \\
\hline volatilised as $\mathrm{NH}_{3}$ & $1.94(0.08)$ & $19.7(0.8)$ & $22.2(1.6)$ & 100 & \\
\hline volatilised from dung* & $0.22(0.05)$ & $2.3(0.5)$ & $2.6(0.6)$ & $11.6(2.7)$ & \\
volatilised from urine* & $1.72(0.05)$ & $17.5(0.9)$ & $19.8(1.3)$ & & $25.5(2.0)$ \\
\hline
\end{tabular}

* The urine-dung split was not measured, but inferred by plausibility arguments from the temporal evolution of the volatilisation rates and the $\mathrm{pH}$ observations (see Sect. "Discussion").

(LW) gain, the balance was excreted as urine and dung (since the cattle were non-lactating). These $\mathrm{N}$ amounts are estimated as follows, and summarised in Table 1.

The amount of dung excreted can be estimated as a fraction of DM intake, where the fraction equals $100 \%$ minus digestibility. The DM digestibility of the pasture was $80.3( \pm 0.6) \%$ (mean \pm SE of 6 feeding occasions), which gives the total dung DM as $74.7( \pm 2.5) \mathrm{kg}$. The $\mathrm{N}$ content of dung DM is assumed to be in proportion to the $\mathrm{N}$ content in the feed DM, thus taken as $2.59 \%$ of dung DM. (This fraction is corroborated by measurements of the initial $\mathrm{N}$ fractions in the four dung pats created on the start day and the following three afternoons, which ranged from $2.10 \%$ to $2.88 \%$.) Hence, the deposited amount of dung-N was $1.93( \pm 0.08) \mathrm{kg}$.

It is estimated that each animal gained on average $1.25( \pm 0.25) \mathrm{kg} \mathrm{LW}$ per day, based on reference tables for nutritional requirements (Agricultural Research Council, $1980)$. For 12 cattle over $3 \mathrm{~d}$, this amounts to $45( \pm 9) \mathrm{kg} \mathrm{LW}$ gain. The amount of $\mathrm{N}$ retained in the weight gain is assumed to be $2.5( \pm 0.25) \%$ of that (default value used by the Helsinki Commission of the European Union), resulting in a total of $1.13( \pm 0.25) \mathrm{kg} \mathrm{N}$ retained. This represents $11.5( \pm 2.6) \%$ of the $\mathrm{N}$ intake.

Subtracting dung- $\mathrm{N}$ and $\mathrm{N}$ retained from the total $\mathrm{N}$ intake provides an estimate of the $\mathrm{N}$ amount deposited with urine, of $6.75( \pm 0.50) \mathrm{kg}$. This represents a daily per-capita excretion of $0.188( \pm 0.014) \mathrm{kg} \mathrm{N} \mathrm{d}^{-1}$ animal $^{-1}$. Combining urine-N and dung-N, the total amount of excreted $\mathrm{N}$ was $8.68( \pm 0.49) \mathrm{kg}$, equivalent to an average application density of $111 \mathrm{~kg} \mathrm{ha}^{-1}$. Urine accounted for $77.8( \pm 1.6) \%$ and dung for $22.2( \pm 1.6) \%$ of the excreted $\mathrm{N}$.

\subsection{Ammonia emissions}

The evolution of $\mathrm{NH}_{3}-\mathrm{N}$ emission rates is shown in Fig. 2, along with the mean $\mathrm{N}$ excretion rates, estimated as the

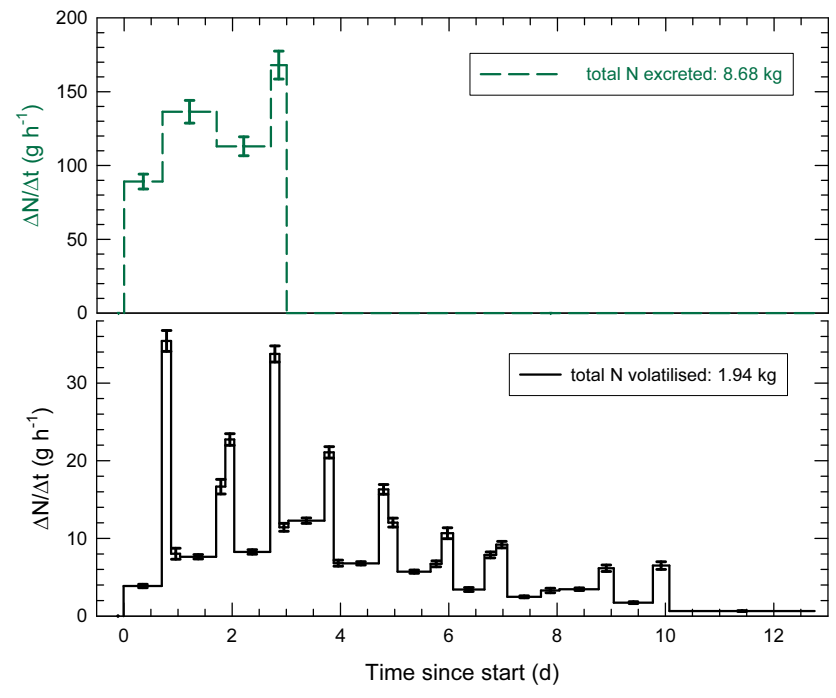

Fig. 2. Temporal evolution of $\mathrm{N}$ excretion rate of 12 cattle during their 3-day presence, estimated as the difference of $\mathrm{N}$ intake and $\mathrm{N}$ retained (top), and $\mathrm{NH}_{3}-\mathrm{N}$ volatilisation rate (bottom). Error bars for the latter represent estimated measurement uncertainty and are placed at the mid-times of the $\mathrm{NH}_{3}$ collection periods, whose lengths are marked by the horizontally constant parts of the connecting solid line.

difference of $\mathrm{N}$ intake and $\mathrm{N}$ retained. While the cattle were present and the amount of excreta was rising, emission rates generally increased. Superimposed on this general trend were strong variations between large daytime emissions and smaller nighttime emissions (nighttime periods are recognisable by their longer duration). These variations are in response to the diurnal temperature cycle and are similar to those observed by Laubach et al. (2012). Absolute emission rates peaked at 35 and $34 \mathrm{~g} \mathrm{~N} \mathrm{~h}^{-1}$ on the first and third day, respectively, equivalent to per-area emissions of 
12.6 and $12.0 \mu \mathrm{g} \mathrm{N} \mathrm{m}^{-2} \mathrm{~s}^{-1}$. After the cattle had departed, emission rates stayed high for another day. For the remaining 9 days, volatilisation rates generally decreased. The residual emission rate over the final collection period, from $10.07 \mathrm{~d}$ to $12.75 \mathrm{~d}$, was only $0.65 \mathrm{~g} \mathrm{~N} \mathrm{~h}^{-1}$, one magnitude less than emission rates of the first week.

The total amount of $\mathrm{NH}_{3}-\mathrm{N}$ volatilised was $1.94 \mathrm{~kg} \mathrm{~N}$, with a cumulative propagated standard error of $0.02 \mathrm{~kg} \mathrm{~N}$, computed as described in Laubach et al. (2012). This represents $19.8( \pm 0.9) \%$ of the cattle's $\mathrm{N}$ intake and $22.4( \pm 1.3) \%$ of the $\mathrm{N}$ excreted (Table 1). Expressed per area, the $\mathrm{N}$ loss was $24.7 \mathrm{~kg} \mathrm{ha}^{-1}$.

\subsection{Evolution of $\mathrm{pH}$ in urine patches and dung pats}

Figure 3 shows the evolution of the $\mathrm{pH}$ at the urine patch and dung pat surfaces and inside the dung pats, with separate symbols for each individual patch or pat (created on successive days). For each urine patch, the maximum soil surface $\mathrm{pH}$, between 8.5 and 9.0, occurred one day after its creation, indicating the completion of urea hydrolysis. After that, the $\mathrm{pH}$ decreased steadily while $\mathrm{NH}_{3}$ volatilisation rates were high (Fig. 2). Six days after the start, the $\mathrm{pH}$ had fallen to below 7.7 for all patches. The two major rainfall events, with $3 \mathrm{~mm}$ and $5 \mathrm{~mm}$ yield, caused temporary increases in urine patch surface $\mathrm{pH}$ and synchronised the subsequent $\mathrm{pH}$ evolution for all four patches. It is unclear, though, whether the rain events had any significant impact on the $\mathrm{NH}_{3}$ emissions.

Initial $\mathrm{pH}$ values at the dung pat surfaces were between 7 and 8 , as at the urine patch surfaces (Fig. 3, middle panel). They then rose more slowly than in the urine and peaked 3 to $4 \mathrm{~d}$ after the dung pat's creation, at a consistent value of 9.5 ( \pm 0.1$)$. After that, the dung surface $\mathrm{pH}$ decreased slowly and steadily, except that all pats showed a secondary peak, $8 \mathrm{~d}$ after the start for the oldest pat and $9 \mathrm{~d}$ after the start for the others (representing ages of 6 to $8 \mathrm{~d}$ for them). Dung surface $\mathrm{pH}$ at the end of the experiment was still elevated, at $8.8( \pm 0.2)$, and consistent between pats.

For each dung pat, the interior $\mathrm{pH}$ (Fig. 3, bottom panel) was consistently lower than the surface $\mathrm{pH}$, and it rose more slowly, peaking about $7 \mathrm{~d}$ after the pat's creation (the exact timing is somewhat uncertain because samples from the same pat were only taken every 3 or $4 \mathrm{~d}$ ). All four pats were sampled at the end of the experiment and showed an interior $\mathrm{pH}$ of $8.4( \pm 0.2)$, still markedly above neutral.

\subsection{Moisture and mineral $\mathrm{N}$ of dung samples}

The dung-interior samples contained 66 to $89 \%$ water on a mass basis (mean \pm SE of 48 samples: $82.7 \pm 0.6 \%$ ), and moisture did not show a trend over time, which means there was plenty of dung solution available throughout. The water content of the dung-crust samples showed no clear trend either. It was significantly lower than in the interior but also more variable, from 8 to $82 \%$ (mean \pm SE of 37 samples was

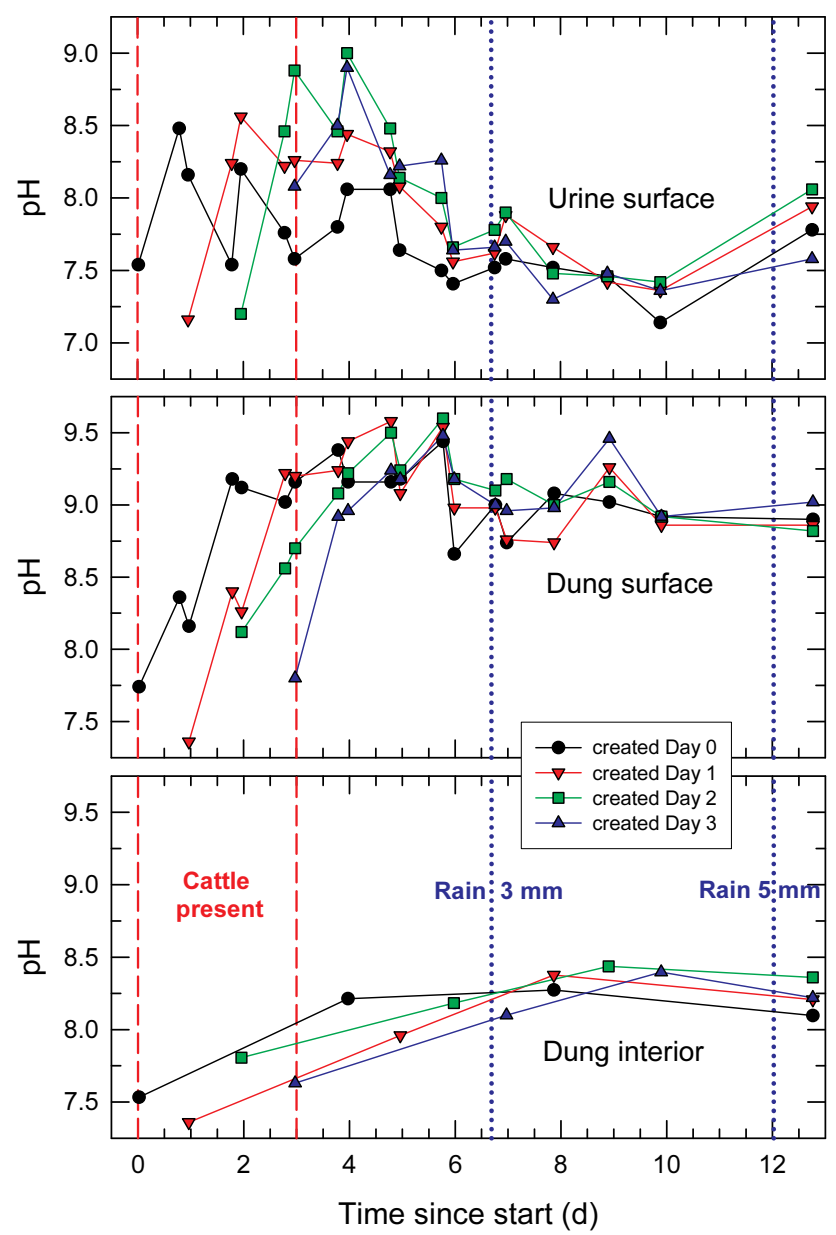

Fig. 3. Temporal evolution of $\mathrm{pH}$ on urine patch surfaces (top panel), dung pat surfaces (middle) and inside dung pats (bottom). The period of cattle presence is indicated by vertical dashed lines, and the two rain events with more than $1 \mathrm{~mm}$ yield are marked by dotted lines.

$49.7 \pm 2.8 \%)$. The variability may partly stem from incomplete separation of dung interior material sticking to the crust sample.

The $\mathrm{NH}_{\mathrm{x}}-\mathrm{N}$ content of the dung interior was significantly correlated to $\mathrm{pH}$ measured in the same samples (Fig. 4a), while $\left[\mathrm{NO}_{2}^{-}-\mathrm{N}\right]$ and $\left[\mathrm{NO}_{3}^{-}-\mathrm{N}\right]$ of the dung interior were not significantly correlated to $\mathrm{pH}\left(R^{2}=0.08\right.$ for either species, not shown). For the dung crusts, neither $\left[\mathrm{NH}_{\mathrm{x}}-\mathrm{N}\right]$ (Fig. 4b) nor $\left[\mathrm{NO}_{2}^{-}-\mathrm{N}\right]$ nor $\left[\mathrm{NO}_{3}^{-}-\mathrm{N}\right]$ correlated to $\mathrm{pH}$.

\section{Discussion}

\subsection{Ammonia loss fractions}

The extent of $\mathrm{NH}_{3}$ volatilisation from dung tends to be much less than from urine with reported $\mathrm{N}$ loss fractions from dung averaging just $1.5 \%$ from studies in England (Ryden et al., 

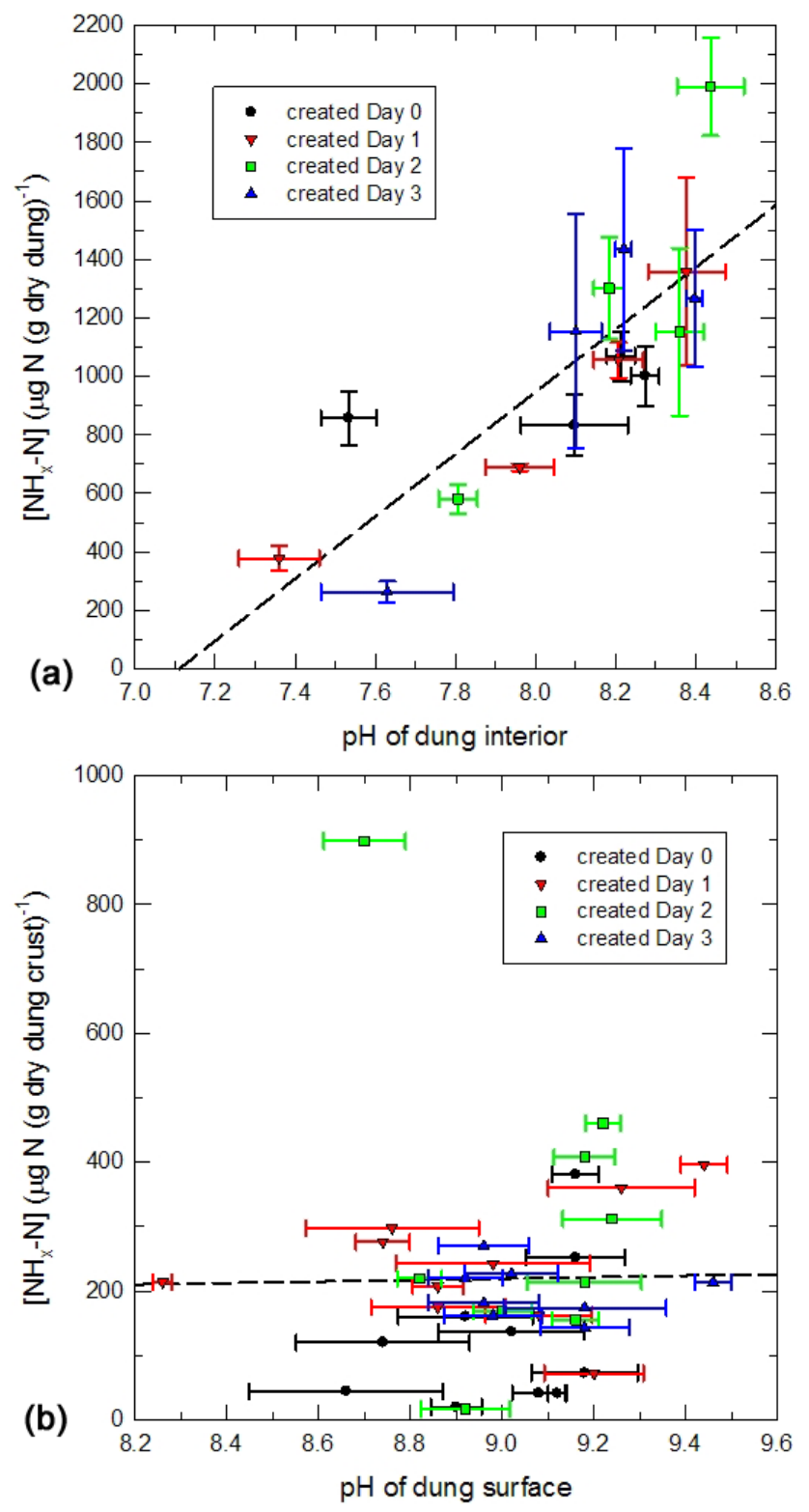

Fig. 4. (a) $\mathrm{NH}_{\mathrm{X}}-\mathrm{N}$ concentration in samples from the dung interior versus $\mathrm{pH}$ of the same samples. The different dung pats are identified by different symbols (same as in Fig. 3). Error bars mark standard errors of the mean of 3 replicates. The dashed line represents linear regression $\left(R^{2}=0.66\right)$. (b) Same for $\mathrm{NH}_{\mathrm{X}}-\mathrm{N}$ concentration of dung-crust samples versus $\mathrm{pH}$ on the dung surface (mean of 5 replicates). The linear regression has $R^{2}=0.0003$.

1987) and Finland (Saarijärvi et al., 2006) and $4.5 \%$ from chamber studies carried out in New Zealand (Sugimoto et al., 1992). The proportion of total urinary-N volatilised as $\mathrm{NH}_{3}-\mathrm{N}$ is typically 10 to $40 \%$, with the higher values during warm summer conditions and the lower values in the cooler seasons (Ball et al., 1979; Whitehead et al., 1989; Whitehead and Raistrick, 1991, 1992; Bol et al., 2004). In New Zealand, Sherlock and Goh (1984) measured $\mathrm{NH}_{3}-\mathrm{N}$ emis- sions for urine-treated plots of $22.2 \%, 24.6 \%$, and $12.2 \%$ of total urinary- $\mathrm{N}$ in summer, autumn, and winter, respectively. The total $\mathrm{N}$ losses from urine and dung combined are therefore most likely of order 10 to $30 \%$. The present result of $22.4 \% \mathrm{~N}$ loss falls into this range, yet the range of reported measurements is even wider, from 3 to $52 \%$ (Petersen et al., 1998).

Past experiments similar to the present one were undertaken by Bussink (1992, 1994), with cattle grazing circular plots repeatedly over the course of a year, and fertilisation of the pasture following each grazing occasion. There, the $\mathrm{N}$ loss fractions for summertime grazing events were of order $15 \%$ only, and in the cooler seasons they were less than $10 \%$. The $\mathrm{N}$ excretion rate (urine and dung combined) reported by Bussink $(1992,1994)$ was typically 40 to $80 \mathrm{~kg} \mathrm{ha}^{-1}$, roughly half of that in the present experiment. The excreta density in the latter was higher because of the unrealistically long period of animal presence. A consequence of this was an increased probability for urine and dung being co-deposited in the same location, which could have increased the rate of urea hydrolysis because of the interaction of urinary urea and faecal urease. This probability can be estimated from the respective number of urinations and defecations and the average dung pat size. An approximate count of dung pats, after the cattle had departed, gave $N=445( \pm 23)$. Dung pat size was not measured and is guessed as $a=0.1 \mathrm{~m}^{2}$. Given the fenced surface area $A=785 \mathrm{~m}^{2}$, the dung cover fraction was thus $p=N a / A=0.057$. This is the probability for a single urination to occur in a defecation's location (regardless of the timing of both events). For cattle, urination counts are typically about $80 \%$ of defecation counts (Haynes and Williams, 1993; White et al., 2001), which gives an estimated total of 356 urinations. Using the binomial probability distribution, it results that the most likely number of urine patches being co-located with a dung pat was 20 . The occurrence of 20 colocations would imply that $5.6 \%$ of all urine-N and $4.5 \%$ of all dung-N was potentially subject to interaction with each other. However, even if such interaction altered the volatilisation rate considerably (e.g. doubled it), the effect of that on the total $\mathrm{N}$ volatilised would still be small (of order $5 \%$ ).

Bussink (1994) showed for his data that on an annual basis, the amount of $\mathrm{N}$ lost as $\mathrm{NH}_{3}$ increased more than linearly with increasing amount of $\mathrm{N}$ applied. Hence, the higher $\mathrm{N}$ application rate in the present experiment may have been a cause for the $\mathrm{N}$ volatilisation rate to be higher than in Bussink's studies. However, when Laubach et al. (2012) mimicked a realistic urine application pattern for grazing cattle, the $\mathrm{NH}_{3}$ loss amounted to $25.7( \pm 0.5) \%$ of the applied urine-N, similar to the present experiment, while the application rate had been equivalent to $30 \mathrm{~kg} \mathrm{ha}^{-1}$ only. This suggests that the $\mathrm{N}$ application rate may be less important than other factors in controlling $\mathrm{N}$ loss rates. Incidentally, in the figure of Bussink (1994) showing the dependence of annual $\mathrm{N}$ loss on $\mathrm{N}$ application, the slope for high amounts of applied $\mathrm{N}$ approaches 0.22 , predicting that $22 \%$ of any 
$\mathrm{N}$ applied in addition to already high $\mathrm{N}$ levels would be volatilised. The present results are compatible with this finding.

\subsection{Contributions of urine and dung to ammonia volatilisation}

In the present experiment, the daily $\mathrm{N}$ losses increased during the first $3 \mathrm{~d}$, while excreta were being voided onto the experimental plot, and then decreased during the following $5 \mathrm{~d}$. This pattern was unambiguously explained by the dominance of volatilisation from urine, which provided the major part of all deposited N. On Days 9 and 10 of the experiment, though, the $\mathrm{NH}_{3}$ volatilisation was larger than on Day 8 (Fig. 5). This secondary maximum in the $\mathrm{NH}_{3}$ loss trajectory occurred at the same time that the $\mathrm{pH}$ of the dung interior reached its overall maximum, and the $\mathrm{pH}$ of the dung surface attained a secondary maximum (Fig. 3). It thus appears plausible that the secondary maximum in $\mathrm{NH}_{3}$ emissions on Day 9 was caused by volatilisation from dung, and that dung emissions also provided the dominant contribution to $\mathrm{N}$ loss thereafter. Similar bimodal curves of $\mathrm{NH}_{3}$ emissions over time were obtained by Jarvis et al. (1989) in experiments on grazed paddocks, and by Kellems et al. (1979) in laboratory experiments with various mixtures of cattle urine and dung, where the larger and earlier peak increased with increasing urine content and the smaller and later peak with increasing dung content. Sugimoto et al. (1992) measured $\mathrm{NH}_{3}$ volatilisation rates from dung and found that they peaked after $15 \mathrm{~d}$ when wet and after $20 \mathrm{~d}$ when dry, during cooler conditions than in the present experiment. This supports the interpretation that a peak in dung emissions at about $9 \mathrm{~d}$ in the current experiment was plausible. It also suggests that volatilisation from dung probably continued at low levels after $13 \mathrm{~d}$, but sampling ceased then because the collected $\mathrm{NH}_{3}$ amounts approached the resolution limit of the method.

In Fig. 5, the transition between the $\mathrm{NH}_{3}$ emissions mainly from urine to those mainly from dung is indicated by a vertical dashed line at $8 \mathrm{~d}$. In reality there is an overlap of the two modes, but for budgeting purposes this is ignored here and it is assumed that all emissions before this time originate from urine, and all emissions thereafter from dung. The former amount to $1.72 \mathrm{~kg} \mathrm{~N}$ and the latter to $0.22 \mathrm{~kg} \mathrm{~N}$, with an uncertainty estimated as $0.05 \mathrm{~kg} \mathrm{~N}$ for either, to account for the crude separation method. This implies that $88.6( \pm 2.6) \%$ of the volatilised $\mathrm{N}$ originated from urine, an even larger fraction than the urine fraction of the deposited $\mathrm{N}(77.8 \%)$. Relative to the total $\mathrm{N}$ excreted, the emissions from urine and dung represent $19.8 \%$ and $2.6 \%$, respectively (Table 1). Relative to the amounts of urine- $\mathrm{N}$ and dung$\mathrm{N}$, of $6.75 \mathrm{~kg}$ and $1.93 \mathrm{~kg}$, respectively, they represent loss rates of $25.5( \pm 2.0) \%$ from urine and $11.6( \pm 2.7) \%$ from dung. The value for urine agrees with that from Laubach et al. (2012), obtained in similar weather conditions. The value for dung exceeds the numbers cited at the start of Sect. 4.1,

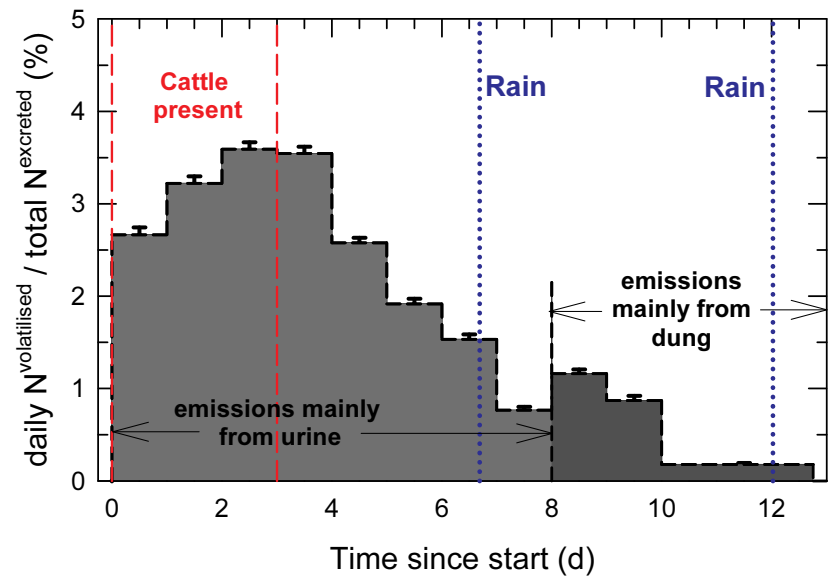

Fig. 5. Day-to-day evolution of $\mathrm{N}$ loss fraction due to volatilisation, relative to the amount of $\mathrm{N}$ excreted by 12 cattle over the first 3 days. The vertical dashed line at $8 \mathrm{~d}$ marks when $\mathrm{N}$ loss rates cease to be dominated by volatilisation from urine, and emissions from dung probably begin to constitute the major fraction. The times of the two rain events with more than $1 \mathrm{~mm}$ yield are marked by dotted lines.

but may still be an underestimate because it potentially excludes emissions after $13 \mathrm{~d}$. Nevertheless, it is less than half the loss rate for urine, hence for refined $\mathrm{NH}_{3}$ inventories it may be justified to define different emission factors for urine and dung.

Even though the urine-dung split inferred here is only based on plausibility arguments, there is no doubt that the absolute amounts of $\mathrm{N}$ volatilised from urine are typically one magnitude larger than those from dung. After $6 \mathrm{~d}$, the soil surface $\mathrm{pH}$ had fallen to below 7.7 for all urine patches. By this time, the area-integrated $\mathrm{NH}_{3}$ emission rate had dropped to less than $10 \mathrm{~g} \mathrm{Nh}^{-1}$ (Fig. 2), and $79 \%$ of all observed emissions had occurred. The main trends for urine patch surface $\mathrm{pH}$ and $\mathrm{NH}_{3}$ emissions are thus correlated, as has been shown previously (Laubach et al., 2012).

\subsection{Processes controlling the volatilisation from urine and dung}

The essential steps for $\mathrm{NH}_{3}$ volatilisation from dung are the same as in urine-treated soil, namely: an elevation in the $\mathrm{pH}$ of the volatilisation surface, $\mathrm{NH}_{4}^{+}$formation in the liquid phase, equilibrium transition of that $\mathrm{NH}_{4}^{+}$into $\mathrm{NH}_{3}$ in the gas phase, and its diffusion through a porous medium into the atmosphere.

In the case of urine, the elevation in soil surface $\mathrm{pH}$ and the formation of $\mathrm{NH}_{4}^{+}$is a direct consequence of the hydrolysis of the urea contained in the urine (Sherlock and Goh, 1985). At summer temperatures, hydrolysis tends to be nearly complete within a few hours, leading to rapid $\mathrm{pH}$ rise and high volatilisation rate in the first couple of days. The same is true for surface-applied slurry (Spirig et al., 2010), where the urea 
Table 2. Estimation of variables required for a resistance-model description of the $\mathrm{NH}_{3}$ volatilisation from dung pats, analogous to that for urine-treated soil patches by Laubach et al. (2012), for Days 6 to 13.

\begin{tabular}{|c|c|c|c|}
\hline Model variable & Obtained range & Input variables & $\begin{array}{l}\text { Method, or Equation in } \\
\text { Laubach et al. (2012) }\end{array}$ \\
\hline dung temperature & 16.0 to $28.5^{\circ} \mathrm{C}$ & soil temperature & extrapolated to surface \\
\hline$\left[\mathrm{NH}_{\mathrm{X}}-\mathrm{N}\right]_{\mathrm{aq}}$ & 207 to $396 \mu \mathrm{g} \mathrm{mL}^{-1}$ & {$\left[\mathrm{NH}_{\mathrm{X}}-\mathrm{N}\right]$ in dry dung, $\left[\mathrm{H}_{2} \mathrm{O}\right]$ in dung } & ratio of inputs \\
\hline $\begin{array}{l}C_{\mathrm{N}, \text { w }} \text { (gaseous equilibrium }\left[\mathrm{NH}_{3}-\mathrm{N}\right] \\
\text { within dung) }\end{array}$ & 4.3 to $24.0 \mathrm{mg} \mathrm{m}^{-3}$ & $\begin{array}{l}\mathrm{pH} \text { of dung interior, dung temperature, } \\
{\left[\mathrm{NH}_{\mathrm{x}}-\mathrm{N}\right]_{\mathrm{aq}}}\end{array}$ & $(6),(7)$ \\
\hline $\begin{array}{l}r_{\mathrm{a}} \text { (aerodynamic resistance } \\
\text { from ground to height } z \text { ) }\end{array}$ & 11 to $117 \mathrm{~s} \mathrm{~m}^{-1 \mathrm{a}, \mathrm{b}}$ & wind speed, stability parameter & (9) \\
\hline $\begin{array}{l}r_{\mathrm{b}} \text { (laminar boundary-layer } \\
\text { resistance) }\end{array}$ & 9 to $44 \mathrm{~s} \mathrm{~m}^{-1} \mathrm{a}$ & friction velocity & (12) \\
\hline $\begin{array}{l}C_{\mathrm{N}, \mathrm{s}} \text { (mean gaseous }\left[\mathrm{NH}_{3}-\mathrm{N}\right] \\
\text { at the soil/dung surface) }\end{array}$ & 23 to $224 \mu \mathrm{g} \mathrm{m}^{-3}$ & $\begin{array}{l}C_{\mathrm{N}}(\text { concentration at height } z), \\
Q_{\mathrm{N}}\left(\text { emission rate of } \mathrm{NH}_{3}-\mathrm{N}\right), r_{\mathrm{a}}, r_{\mathrm{b}}\end{array}$ & (16) \\
\hline $\begin{array}{l}r_{\mathrm{S}} \text { (dung crust resistance) } \\
\text { tortuosity of dung }\end{array}$ & $\begin{array}{l}94 \text { to } 960 \mathrm{~s} \mathrm{~m}^{-1 \mathrm{c}} \\
0.05 \text { to } 0.47^{\mathrm{d}}\end{array}$ & $\begin{array}{l}C_{\mathrm{N}, \mathrm{w}}, C_{\mathrm{N}, \mathrm{s}}, Q_{\mathrm{N}} \\
r_{\mathrm{S}}\end{array}$ & $\begin{array}{l}(22) \\
(18)\end{array}$ \\
\hline
\end{tabular}

a Depends on roughness length, assumed as $0.02 \mathrm{~m}$.

${ }^{b}$ Increases with height (maximum range given).

${ }^{c}$ Depends on dung cover fraction, assumed as 0.057 .

${ }^{\mathrm{d}}$ Depends on dung crust thickness, assumed as $1 \mathrm{~mm}$.

hydrolysis is often already completed at the time of application. As volatilisation proceeds, a subsequent reduction in surface $\mathrm{pH}$ occurs as a consequence of the chemical transformation of $\mathrm{NH}_{4}^{+}$to $\mathrm{NH}_{3}$ with the accompanying release of a proton into the soil solution. This re-acidifies the soil surface and after some time a surface soil $\mathrm{pH}$ arises which is inadequate to sustain further $\mathrm{NH}_{3}$ volatilisation (Sherlock and Goh, 1985). In the present experiment, that time was approximately $8 \mathrm{~d}$.

In the case of dung pats, the initial rise in dung-surface $\mathrm{pH}$ is not due to urea hydrolysis since dung contains little or no urea (Ryden et al., 1987; Kirchmann and Lundvall, 1998). Instead the rise in $\mathrm{pH}$ is readily explained by the transformation of the bicarbonate ion, $\mathrm{HCO}_{3}^{-}$, into $\mathrm{CO}_{2}$ (Sommer and Sherlock, 1996). In contrast to the transformation of $\mathrm{NH}_{4}^{+}$to $\mathrm{NH}_{3}$, which releases a proton, the transformation of $\mathrm{HCO}_{3}^{-}$ into $\mathrm{CO}_{2}$ releases a hydroxyl ion $\left(\mathrm{OH}^{-}\right)$into the dung pat thereby increasing its $\mathrm{pH}$. Despite a lack of urea hydrolysis, dung contains some $\mathrm{NH}_{\mathrm{x}}$. In the dung interior, its concentration ranged from 263 to $1990 \mu \mathrm{g} \mathrm{N}$ (g dry dung) $)^{-1}$ (Fig. 4a), with a mean of $1024 \mu \mathrm{g} \mathrm{N}$ (g dry dung) $)^{-1}$. The latter value represented only $4 \%$ of the total $\mathrm{N}$ content of the dung, and the estimated $\mathrm{N}$ release from dung over $13 \mathrm{~d}$ was 3 times larger, which means new $\mathrm{NH}_{\mathrm{x}}$ must have been formed in the dung on a time scale of days, rather than hours, comparable to the time scale of the volatilisation process. A complete model of the dynamics of volatilisation from dung (not derived in this study) must therefore include the chemistry of $\mathrm{NH}_{\mathrm{x}}$ formation.

In the dung interior, $\left[\mathrm{NH}_{\mathrm{x}}-\mathrm{N}\right]$ was positively correlated to $\mathrm{pH}\left(R^{2}=0.66\right.$, Fig. $\left.4 \mathrm{a}\right)$, almost as strongly as it was in the urine-patch soil samples of Laubach et al. (2012), where $R^{2}=0.77$. Such a high correlation between $\mathrm{pH}$ and $\left[\mathrm{NH}_{\mathrm{X}}-\mathrm{N}\right]$ in dung was also reported by Kirchmann and Lundvall (1998). The regression line in Fig. 4a has a slope of $1064 \mu \mathrm{g} \mathrm{N}$ (g dry dung) ${ }^{-1}$ per $\mathrm{pH}$ unit and predicts vanishing $\left[\mathrm{NH}_{\mathrm{x}}-\mathrm{N}\right]$ at a $\mathrm{pH}$ of 7.1 , i.e. for near-neutral solution. Together with the high moisture content, these data suggest that the dung pats contained all necessary ingredients to build up considerable $\mathrm{NH}_{3}$ volatilisation potential. The actual volatilisation rate was controlled by the permeability of the solid dung crust, discussed next.

\subsection{Resistance of the dung crust to $\mathrm{NH}_{3}$ exchange}

Laubach et al. (2012) employed a simple resistance model to understand the dynamics of $\mathrm{NH}_{3}$ volatilisation from urinetreated soil. Considering a dung pat as a porous medium, similar to the topsoil layer, the same physical principles can be applied to describe its exchange of matter with the atmosphere. To be meaningful, this approach is restricted here to the time period when emissions from urine did not overwhelm emissions from dung, i.e. from Day 6 onwards when dung $\mathrm{pH}$ exceeded urine $\mathrm{pH}$ (Fig. 3).

The model comprises three sequences of steps (Table 2). The first task is to compute the gaseous equilibrium $\mathrm{NH}_{3}$ concentration in the dung interior, from $\mathrm{pH}$, temperature, and aqueous $\left[\mathrm{NH}_{\mathrm{x}}-\mathrm{N}\right]$ in the dung. The $\mathrm{pH}$ was measured in triplicate (Fig. 3). Dung temperature was estimated by extrapolating the soil temperatures from two depths towards the surface. The value of $\left[\mathrm{NH}_{\mathrm{x}}-\mathrm{N}\right]_{\mathrm{aq}}$ was taken as the ratio of $\mathrm{NH}_{\mathrm{x}}$ and $\mathrm{H}_{2} \mathrm{O}$ contents of the dung samples. This assumes that all $\mathrm{NH}_{\mathrm{x}}$ found in the dry samples had previously been dissolved 
in the moisture content of the dung, which may be an overestimate. The resulting gaseous equilibrium $\left[\mathrm{NH}_{3}-\mathrm{N}\right]$ ranges from 4300 to $24000 \mathrm{\mu g} \mathrm{m}^{-3}$, typically with $20 \%$ uncertainty (assuming $1 \mathrm{~K}$ temperature error and including sampling errors of the other inputs).

The second task is to compute the atmospheric resistance and then use it, together with the measured $\mathrm{NH}_{3}$ emission rate and $\mathrm{NH}_{3}$ concentrations in the air, to infer the spatial average of $\left[\mathrm{NH}_{3}-\mathrm{N}\right]_{\mathrm{g}}$ at the soil (and dung) surface. The atmospheric resistance consists of an aerodynamic (turbulent) part, $r_{\mathrm{a}}$, and a laminar-boundary-layer part, $r_{\mathrm{b}}$. Both depend on roughness length, derived as $2 \mathrm{~cm}$ from the wind profiles, and both decrease with increasing wind speed. Here, typical values found for $r_{\mathrm{a}}+r_{\mathrm{b}}$ were 50 to $80 \mathrm{~s} \mathrm{~m}^{-1}$, and the resulting $\left[\mathrm{NH}_{3}-\mathrm{N}\right]_{\mathrm{g}}$ at the soil surface ranged from 23 to $224 \mu \mathrm{g} \mathrm{m}^{-3}$.

The third task is to use the measured $\mathrm{NH}_{3}$ emission rate and the concentration difference between inside and outside of the dung crust to derive a dung crust resistance, $r_{\mathrm{s}}$. For this to be accurate, it would be necessary that $\mathrm{NH}_{3}$ emissions from urine had ceased. As this is not strictly true, the result should be interpreted as a magnitude estimate only. Further, the equilibrium concentration needs to be scaled with the area fraction within the circle covered by dung pats, which was estimated in Sect. 4.1 as $p=0.057$. Multiplying the equilibrium concentration from above by $p$ gives 240 to $1400 \mu \mathrm{g} \mathrm{m}^{-3}$, which is a factor 3 to 12 larger than $\left[\mathrm{NH}_{3}-\mathrm{N}\right]_{\mathrm{g}}$ at the soil surface. With this, $r_{\mathrm{s}}$ is obtained as 94 to $960 \mathrm{~s} \mathrm{~m}^{-1}$. This is the same magnitude as the value of $119 \mathrm{~s} \mathrm{~m}^{-1}$ found by Olesen and Sommer (1993) for the resistance of a thin surface crust on slurry tanks.

Since $r_{\mathrm{S}}$ was 2 to 20 times larger than $r_{\mathrm{a}}+r_{\mathrm{b}}$, the dung crust provided the dominant resistance to volatilisation. Assuming a typical thickness of about $1 \mathrm{~mm}$, the tortuosity of the dung crust can be estimated from $r_{\mathrm{s}}$. This gives the following values for Days $6,7,8,9,10$, and 13 , respectively: $0.21,0.47,0.11,0.14,0.08$, and 0.05 . All but the second value are within the range obtained for the soil in the experiment of Laubach et al. (2012), suggesting that the dung crust can indeed be modelled as a porous medium similar to soil. The drop in tortuosity over the last days corresponds with wetting by rain, which provides a plausible mechanism by reducing the air-filled pore space in the dung crust.

It is thus possible to understand the dynamics of the dung volatilisation with the resistance model. For the present experiment, the values in Table 2 should be taken as order-ofmagnitude indications, given the various sources of uncertainty for some of the required parameters.

\section{Concluding remarks}

In two experiments, one with a regular urine-patch pattern deposited onto pasture (Laubach et al., 2012), the other with cattle excreta in situ, the observed $\mathrm{NH}_{3}$ emis- sion rates were consistent with each other, and also with emission rates found elsewhere in similar weather conditions. Expressed as fractions of deposited nitrogen, the $\mathrm{N}$ losses were $25.7( \pm 0.5) \%$ from the urine-patch pattern, and $22.4( \pm 1.3) \%$ from the cattle excreta. As both experiments were conducted at the warmest time of the year, the emission rates were at the upper end of the range likely to occur in New Zealand.

The second experiment, reported here, also investigated some aspects of the dung processes that were different to those in urine patches. Over time the $\mathrm{pH}$ in the dung interior increased above 8 and was positively correlated with $\left[\mathrm{NH}_{\mathrm{X}}-\right.$ $\mathrm{N}]$, creating conditions conducive to volatilisation. To some degree this volatilisation occurs, though it is slowed down by the presence of the dung crust, providing a resistance to gaseous exchange between dung interior and the ambient air that is about one magnitude larger than the atmospheric resistances. In effect, the fractional loss of $\mathrm{N}$ from dung is less than half that from urine. Here, quantification of separate volatilisation rates for urine and dung was only by inference from the bimodal shape of the emissions time series; yet this inferred result is fully corroborated by the literature cited in Sects. 4.1. and 4.2.

\section{Appendix A}

\section{Sensitivity of ammonia electrode to volatile amines}

As mentioned in Sect. 2.6, the $\mathrm{NH}_{3}$ concentrations in the extracted solutions measured with the $\mathrm{NH}_{3}$ electrode exceeded those measured with the CCA systematically by a factor 2 to 3. The CCA results appeared plausible and were confirmed by comparison to those obtained using an FIA. This suggests that the electrode measurements were subject to an unanticipated analytical artefact, possibly interference by other basic compounds. Volatile amines (VA) are plausible candidates for this, as they are known to be emitted from animal husbandry (Schade and Crutzen, 1995). Indeed, the independent $\mathrm{N}$ analysis of two samples (Hill Laboratories, Hamilton, New Zealand) found that total Kjeldahl- $\mathrm{N}$ exceeded $\mathrm{NH}_{\mathrm{x}}-\mathrm{N}$ significantly, by $20 \%$ and $100 \%$, respectively. Evidently, some non- $\mathrm{NH}_{\mathrm{X}}-\mathrm{N}$ compounds must have been present, which may have been VA. If the cattle or their dung emitted VA, these would have been collected by the $\mathrm{NH}_{3}$ samplers and then, in the extracted solution, could have biased the electrode reading just as if additional $\mathrm{NH}_{4}^{+}$ions had been present. Such a bias could not have occurred in earlier experiments with urea fertiliser and urine patches (Sherlock et al., 1995; Laubach et al., 2012), because there were no potential sources of VA at the respective sites.

According to Schade and Crutzen (1995), trimethylamine (TMA) is the dominant VA component emitted. Kuhn et al. (2011) investigated the co-emissions of TMA and $\mathrm{NH}_{3}$ from cattle-related sources. They found molar emission 
ratios [TMA]/[ $\left.\mathrm{NH}_{3}\right]$ of 0.017 to 0.078 from rumen juice samples, while emission ratios for dung and slurry were 3 orders of magnitude smaller. These results suggest that cattle eructate significant amounts of TMA from their rumen contents, along the same pathway as for their $\mathrm{CH}_{4}$ emissions. Dung, though, appears not to be a significant TMA source. Further, Kuhn et al. (2011) found TMA/ $\mathrm{NH}_{3}$ emission ratios of order 0.002 to 0.004 from hay and silage. It is unclear whether this result would apply to freshly-cut pasture. As most of the feed was eaten rather quickly in the present experiment, and refused feed was removed before offering the next round, it appears unlikely that the grass acted as a significant source of VA. It should be noted that the discrepancy between electrode and CCA was reduced after the cattle had left, but did not disappear completely: at the two uppermost heights (which measure the lowest concentrations), the ratio of electrode to CCA readings approached 1 from about Day 6, but at the lower three heights, it stayed closer to 2 .

Here, it was not attempted to reproduce in detail the influence of TMA, or other VA, on measurements of known $\mathrm{NH}_{4}^{+}$concentrations with the electrode, since that was beyond the scope of the current study. The $\mathrm{NH}_{3}$ electrode is essentially a modified $\mathrm{pH}$ electrode. It relies on the diffusion of $\mathrm{NH}_{3}$ molecules present in the sample (which is previously made strongly basic with added $\mathrm{OH}^{-}$) through a hydrophobic membrane to the electrode surface. It is known that the basicity levels of VA (CRC, 2007) are generally significantly greater than the basicity of $\mathrm{NH}_{3}$, implying that even low VA concentrations, if present in the sample, could produce elevated electrode readings. For a crude estimate, it may be assumed that VA diffuse through the hydrophobic membrane like $\mathrm{NH}_{3}$, and that their aqueous solubilities (i.e. Henry's Law coefficients) are comparable to $\mathrm{NH}_{3}$. Then, a molar ratio of methylamine to $\mathrm{NH}_{\mathrm{x}}-\mathrm{N}$ of 0.05 , or a molar TMA/ $/ \mathrm{NH}_{3}$ ratio of 0.02 , respectively, would be sufficient to cause an error of a factor of 2 in the $\mathrm{NH}_{\mathrm{x}}-\mathrm{N}$ reading, thanks to the VA's greater basicity. Subsequent tests involving modest additions of trimethylamine hydrochloride (TMAHCl) to $\mathrm{NH}_{4}^{+}-\mathrm{N}$ solutions of known concentration, made basic with added $\mathrm{OH}^{-}$, did produce marked changes in electrode readings broadly consistent with the above estimates. Hence, it is likely that only small amounts of VA need to be trapped in the $\mathrm{NH}_{3}$ sampler, along with the $\mathrm{NH}_{3}$, for the results to be wildly inaccurate. Further investigation is needed to more fully validate this conjecture.

\section{Supplementary material related to this article is available online at: http://www.biogeosciences.net/10/ 327/2013/bg-10-327-2013-supplement.pdf.}

Acknowledgements. This work was funded by New Zealand's Ministry for Agriculture and Forestry in the Sustainable Land Management and Climate Change (SLMACC) programme. Thanks are due to Nathan Paton and several student helpers for handling the cattle as well as harvesting, weighing and distributing their feed, to Neil Smith and Tony McSeveny for technical support in the field, and to Diane Kearney for performing the CCA analyses.

Edited by: C. Spirig

\section{References}

Agricultural Research Council: The Nutrient Requirements of Ruminant Livestock, Commonwealth Agricultural Bureaux, Farnham Royal, England, 1980.

Ball, R., Keeney, D. R., Theobald, P. W., and Nes, P.: Nitrogen balance in urine-affected areas of a New Zealand pasture, Agron. J., 71, 309-314, doi:10.2134/agronj1979.00021962007100020022x, 1979.

Barthelmie, R. J. and Pryor, S. C.: Implications of ammonia emissions for fine aerosol formation and visibility impairment: A case study from the Lower Fraser Valley, British Columbia, Atmos. Environ., 32, 345-352, 1998.

Beauchamp, E. G., Kidd, G. E., and Thurtell, G. W.: Ammonia volatilization from sewage sludge applied to the field, J. Environ. Qual., 7, 141-146, 1978.

Bobbink, R., Boxman, D., Fremstad, E., Heil, G., Houdijk, A., and Roelofs, J.: Critical loads for nitrogen eutrophication of terrestrial and wetland ecosystems based upon changes in vegetation and fauna, in: Critical loads for nitrogen, Report to the Nordic Council of Ministers, edited by: Grennfelt, P. and Thörnelöf, E., 111-159, Copenhagen, Denmark, 1992.

Bol, R., Petersen, S. O., Christofides, C., Dittert, K., and Hansen, M. N.: Short-term $\mathrm{N}_{2} \mathrm{O}, \mathrm{CO}_{2}, \mathrm{NH}_{3}$ fluxes, and N/C transfers in a Danish grass-clover pasture after simulated urine deposition in autumn, J. Plant Nutr. Soil Sc., 167, 568-576, 2004.

Bussink, D. W.: Ammonia volatilization from grassland receiving nitrogen fertilizer and rotationally grazed by dairy cattle, Fert. Res., 33, 257-265, 1992.

Bussink, D. W.: Relationships between ammonia volatilization and nitrogen fertilizer application rate, intake and excretion of herbage nitrogen by cattle on grazed swards, Fert. Res., 38, 111121, 1994.

CRC: CRC Handbook of Chemistry and Physics, 88th Edn. 20072008, edited by: Lide D. R., 8-42-8-51, CRC Press, 2007.

Denmead, O. T.: Novel meteorological methods for measuring trace gas fluxes, Philos. T. R. Soc. Lond., A351, 383-396, 1995.

Fenn, L. B. and Hossner, L. R.: Ammonia volatilisation from ammonium or ammonium-forming nitrogen fertilizers, Adv. Soil S., 1, 123-169, 1985.

Haynes, R. J. and Williams, P. H.: Nutrient cycling and soil fertility in the grazed pasture ecosystem, Adv. Agron., 49, 119-199, 1993.

Jarvis, S. C., Hatch, D. J., and Roberts, D. H.: The effects of grassland management on nitrogen losses from grazed swards through ammonia volatilization; the relationship to excretal $\mathrm{N}$ returns from cattle, J. Agr. Sci., 112, 205-216, 1989.

Kellems, R. O., Milner, J. R., and Church, D. C.: Effect of ration, waste composition and length of storage on the volatilization of 
ammonia, hydrogen sulfide and odors from cattle waste, J. Anim. Sci., 48, 436-445, 1979.

Kirchmann, H. and Lundvall, A.: Treatment of solid animal manures: identification of low $\mathrm{NH}_{3}$ emission practices, Nutr. Cycl. Agroecosys., 51, 65-71, 1998.

Kuhn, U., Sintermann, J., Spirig, C., Jocher, M., Ammann, C., and Neftel, A.: Basic biogenic aerosol precursors: Agricultural source attribution of volatile amines revised, Geophys. Res. Lett., 38, L16811, doi:10.1029/2011GL047958, 2011.

Laubach, J., Taghizadeh-Toosi, A., Sherlock, R. R., and Kelliher, F. M.: Measuring and modelling ammonia emissions from a regular pattern of cattle urine patches, Agr. Forest Meteorol., 156, 1-17, 2012

Leuning, R., Freney, J. R., Denmead, O. T., and Simpson, J. R.: A sampler for measuring atmospheric ammonia flux, Atmos. Environ., 19, 1117-1124, 1985.

Mosier, A. R., Delgado, J. A., Cochran, V. L., Valentine, D. W., and Parton, W. J.: Impact of agriculture on soil consumption of atmospheric $\mathrm{CH}_{4}$ and a comparison of $\mathrm{CH}_{4}$ and $\mathrm{N}_{2} \mathrm{O}$ flux in subarctic, temperate and tropical grasslands, Nutr. Cycl. Agroecosys., 49, 71-83, 1997.

Nemitz, E., Dorsey, J. R., Flynn, M. J., Gallagher, M. W., Hensen, A., Erisman, J.-W., Owen, S. M., Dämmgen, U., and Sutton, M. A.: Aerosol fluxes and particle growth above managed grassland, Biogeosciences, 6, 1627-1645, doi:10.5194/bg-6-16272009, 2009.

Olesen, J. E. and Sommer, S. G.: Modelling effects of wind speed and surface cover on ammonia volatilization from stored pig slurry, Atmos. Environ., 27A, 2567-2574, 1993.

Petersen, S. O., Sommer, S. G., Aaes, O., and Søegaard, K.: Ammonia losses from urine and dung of grazing cattle: Effect of $\mathrm{N}$ intake, Atmos. Environ., 32, 295-300, 1998.

Ryden, J. C., Whitehead, D. C., Lockyer, D. R., Thompson, R. B., Skinner, J. H., and Garwood, E. A.: Ammonia emission from grassland and livestock production systems in the UK, Environ. Pollut., 48, 173-184, 1987.

Saarijärvi, K., Mattila, P. K., and Virkajärvi, P.: Ammonia volatilization from artificial dung and urine patches measured by the equilibrium concentration technique (JTI method), Atmos. Environ., 40, 5137-5145, 2006.

Schade, G. W. and Crutzen, P. J.: Emission of aliphatic-amines from animal husbandry and their reactions - potential source of $\mathrm{N}_{2} \mathrm{O}$ and HCN, J. Atmos. Chem., 22, 319-346, 1995.

Sherlock, R. R. and Goh, K. M.: Dynamics of ammonia volatilization from simulated urine patches and aqueous urea applied to pasture. I. Field experiments, Fert. Res., 5, 181-195, 1984.

Sherlock, R. R. and Goh, K. M.: Dynamics of ammonia volatilization from simulated urine patches and aqueous urea applied to pasture. II. Theoretical derivation of a simplified model, Fert. Res., 6, 3-22, 1985.
Sherlock, R. R., Freney, J. R., Smith, N. P., and Cameron, K. C.: Evaluation of a sampler for assessing ammonia losses from fertilized fields, Fert. Res., 21, 61-66, 1989.

Sherlock, R. R., Freney, J. R., Bacon, P. E., and van der Weerden, T. J.: Estimating ammonia volatilization from unsaturated urea fertilized and urine affected soils by an indirect method, Fert. Res., 40, 197-205, 1995.

Sherlock, R. R., Jewell, P., and Clough, T.: Review of New Zealandspecific FracGASM and FracGASF emission factors, Report to the Ministry of Agriculture and Forestry (Contract MAFPOL/CP02 AG-INVENT-XXA), 2008.

Sintermann, J., Neftel, A., Ammann, C., Häni, C., Hensen, A., Loubet, B., and Flechard, C. R.: Are ammonia emissions from fieldapplied slurry substantially over-estimated in European emission inventories?, Biogeosciences, 9, 1611-1632, doi:10.5194/bg-91611-2012, 2012.

Sommer, S. G. and Sherlock, R. R.: pH and buffer component dynamics in the surface layers of animal slurries, J. Agr. Sci., Cambridge, 127, 109-116, 1996.

Spirig, C., Flechard, C. R., Ammann, C., and Neftel, A.: The annual ammonia budget of fertilised cut grassland - Part 1: Micrometeorological flux measurements and emissions after slurry application, Biogeosciences, 7, 521-536, doi:10.5194/bg-7-5212010, 2010.

Sugimoto, Y., Ball, P. R., and Theobald, P. W.: Dynamics of nitrogen in cattle dung on pasture, under different seasonal conditions. 1. Breakdown of dung and volatilization of ammonia, Journal of the Japanese Society of Grassland Science, 38, 160-166, 1992.

van der Eerden, L. J. M.: Toxicity of ammonia to plants, Agr. Environ., 7, 223-235, 1982.

White, S. L., Shelfield, R. E., Washburn, S. P., King, L. D., and Green Jr., J. T. : Spatial and time distribution of dairy cattle excreta in an intensive pasture system, J. Environ. Qual., 30, 2180-2187, 2001.

Whitehead, D. C. and Raistrick, N.: Effects of some environmental factors on ammonia volatilization from simulated livestock urine applied to soil, Biol. Fert. Soils, 11, 279-284, 1991.

Whitehead, D. C. and Raistrick, N.: Effects of plant material on ammonia volatilization from simulated livestock urine applied to soil, Biol. Fert. Soils, 13, 92-95, 1992.

Whitehead, D. C., Lockyer, D. R., and Raistrick, N.: Volatilization of ammonia from urea applied to soil: influence of hippuric acid and other constituents of livestock urine, Soil Biol. Biochem., 21, 803-808, 1989. 